Удк 004.514:339.138:338.48

DOI: https://doi.org/10.32851/2708-0366/2021.10.8

Лук'янець А.B. старший викладач кафедри туризму та готельно-ресторанної справи, Вінницький торговельно-економічний інститут Київського національного торговельно-економічного університету ORCID: https://orcid.org/0000-0002-9973-5386

Луценко О.І. старший викладач кафедри маркетингу та реклами,

Вінницький торговельно-економічний інститут Київського національного торговельно-економічного університету

ORCID: https://orcid.org/0000-0002-2139-5553

Lukianets Alla, Lutsenko Oleksandra Vinnytsia Institute of Trade and Economics of Kyiv National University of Trade and Economics

\title{
ЗАСТОСУВАННЯ ГРАФІЧНОГО ДИЗАЙНУ У ЦИФРОВОМУ МАРКЕТИНГУ ТУРИСТИЧНОГО БІЗНЕСУ
}

\section{APPLICATION OF GRAPHIC DESIGN IN DIGITAL MARKETING OF TOURISM BUSINESS}

У статті графічний дизайн розглядається як важлива складова частина иифрового маркетингу, щзо сприяе розвитку туристичного бізнесу. Туристичний бізнес в Україні та світі зазнає реорганізації за рахунок иифровізації економічного суспільства. Своєю чергою, маркетологи туристичної індустрії змушені шукати нові способи збільшення попиту на туристичні продукти окремих компаній, саме тому постає потреба у використанні цифрового маркетингу, зокрема таких його методів, як: SEO-оптимізачія, SMO-оптимізація, SMM-медіамаркетинг, етаil-маркетинг, контекстна реклама, SEM, мобільний маркетинг та ремаркетинг. Оскільки кожен із иих методів не може бути реалізований без застосування графічного дизайну, а цифррова диференціачія конкурентів на туристичному ринку широко використовується сьогодні, дослідження цьього складника є актуальним.

Ключові слова: туристичний бізнес, туристична індустрія,циирровізація, циифровий маркетинг, графічний дизайн.

В статье графический дизайн рассматривается как важная составная часть ииифрового маркетинга, способствующая развитию туристического бизнеса. Туристический бизнес в Украине и мире подвергается реорганизации за счет иифровизации экономического общества. В свою очередь, маркетологи туристической индустрии вынуждены искать новые способы увеличения спроса на туристические продукты отдельных компаний. Именно поэтому возникает потребность в использовании циифрового маркетинга, а именно таких его методов, как SEO-оптимизачия, SMO-оптимизаиия, SMM-медиамаркетинг, етаіl-маркетинг, контекстная реклама, SEM, мобильный маркетинг и ремаркетинг. Поскольку каждый из этих методов не может быть реализован без применения графического дизайна, а иифровая дифференцииаиия конкурентов на туристическом рынке широко используется сегодня, исследование этой составляющей является актуальным.

Ключевые слова: туристический бизнес, туристическая индустрия, ичирровизация, ичифровой маркетинг, графический дизайн.

Statistical graphic design looks like an important warehouse for digital marketing for the development of a tourist business. Tourist business in Ukraine and society is recognized for reorganization for the development of digitalization of the economy. In their turn, marketers of the tourism industry will take advantage of the new ways to get better on the tourism products of the company. The same will be required by the victorious digital marketing, and the very same methods, such as: SEO-optimization, SMO-optimization, SMM media-marketing, E-mail 
marketing, contextual advertising, SEM, mobile marketing and remarketing. Oscillations of leather from these methods cannot be realized without the provision of graphic design, and the digital differentiation of competitors on the tourist market is widely promoted today, until the price of warehouse growth is kept up to date. The research summarizes and investigates methods digital marketing and its application in key components of graphic design. As a result of researching the demand for online advertising, we concluded that there is a growing interest in the automation of social media and the creation of dynamic content. This can also be observed in the tourism industry. Thus, tourism in the virtual market depends almost entirely on quality, graphic design, format description, means of transmission and storage of information. We have determined that high-quality graphic design increases the value of the company, and it also strengthens the reputation and professional image. High-quality visualization not only attracts the attention of the consumer, but can also be the key to gaining the trust of tourists, which will easily expand the target audience. Also in the article, we gave examples of layout design for the design of an advertising profile on the social network Instagram. But they concluded that tourist graphics are intuitive and combined with real photos of people and picturesque places, enhances the artistic effects of advertising, thus causing emotional resonance of customers. In turn, this reinforces and is the final stage of the digital marketing strategy.

Key words: travel business, travel industry, digitalization, digital marketing, graphic design.

Постановка проблеми. Сучасні мандрівники більше не покладаються лише на рекомендації туристичних агентів чи статті в журналах, щоб вирішити, куди поїхати у свій наступний відпочинок. Кожен потенційний клієнт туристичного агентства хоче, аби пошук ідеального місця релаксу був максимально інформативним і мінімально затратним. Для вибору місця та сценарію подорожей зараз існують різні джерела віртуальної комунікації: канали соціальних мереж, блоги, онлайн-платформи, лендінги та сайти, що $є$ фундаментальною перевагою цифрового маркетингу перед традиційним, адже приносить більше охоплення аудиторії.

Результатом роботи такого виду маркетингу в туристичному бізнесі стала зміна споживчої поведінки мандрівників. Тепер економічно вигідні пропозиції перейшли на другий план, оскільки клієнти надають превагу іміджу туристичних агентств в Інтернет-просторі. Необхідно звернути увагу на те, що правильно побудована та візуально спроєктована реклама викликає реакцію туристичного стимулу, побудова якого неможлива без застосування графічного дизайну у каналах цифрового маркетингу.

Аналіз останніх досліджень і публікацій. Туризм та рекреація як соціально-економічне явище, що постійно розвивається та змінюється відносно макро- та мікроекономічних показників, має велику кількість визначень, які, відповідно до змін самого туризму та рекреації, постійно вдосконалюються та допрацьовуються [2]. Цифровий маркетинг забезпечує постійну інтерактивну діяльність між клієнтом та вибраним туристичним бізнес-середовищем.

Дослідженням впливу цифровізації на розвиток туристичного бізнесу займалися такі вітчизняні та зарубіжні вчені, як Н. Савицька, яка здійснила обгрунтування засад стратегії та тактики маркетингу в соціальних мережах на ринку В2С [7]; М. Окландер зі співавторами, які окреслили основні напрями й можливості розвитку цифрового маркетингу як специфічної форми маркетингу в умовах інформатизації суспільства [5]. Основні тенденції розвитку маркетингових комунікацій в Україні доволі повно викладено в дослідженнях С. Ковальчук та М. Лазебник [3]. У сфері маркетингового забезпечення розвитку туризму цікавими є доробки I. Криховецького, котрий конкретизував методичні аспекти маркетингових досліджень у цій сфері та виявив умови, за яких задовольняється попит населення в туристичних способах [4]. Звертають увагу на зростання потенціалу впливу сучасних маркетингових технологій на розвиток бізнесу й інші науковці, проте стосовно сфери розвитку туризму таких досліджень недостатньо. Водночас визначення можливостей сучасних маркетингових технологій у підтриманні й посиленні розвитку сфери туризму є важливим завданням, що має не лише наукове, а й практичне значення, оскільки ця сфера є однією з найприбутковіших галузей світової 
економіки, забезпечуючи зростання надходжень у бюджет країни за рахунок ефективного використання ії природного, рекреаційного й культурно-історичного потенціалів.

Графічний дизайн - один 3 ключових компонентів підвищення впізнаваності бренду, що впливає на процес прийняття рішень клієнтом, засіб, що визначив пріоритетність використання цифрового маркетингу в економічних системах бізнесу України та світу. Ефективністю застосування графічного дизайну займалися $Є$. Ромата, А. Владимирська, Б. Дурняк, А. Батюк, Ю. Афанасьєв.

Формулювання цілей статті. Незважаючи на наявність значної кількості наукових праць із теми використання цифрового маркетингу в туристичному бізнесі, можемо зробити висновок, що застосування графічного дизайну у цих сферах вивчалося недостатньо, тому дослідження ролі дизайну реклами залишаються актуальними та потребують подальшого опрацювання.

Виклад основного матеріалу. Сучасний етап економічного розвитку України та світу показує, що туристичний бізнес став одним із найбільш динамічних, гнучких та високоприбуткових сегментів, що безупинно розвивається (рис. 1).

Туристичні подорожі стали важливим атрибутом життя кожної людини. Завдяки ним ми маємо змогу ознайомитися з культурно-історичною спадщиною народів світу, розширити свій кругозір та порівняти стандарти життя, побут та довкілля країн нашої планети.

У пошуках способів поліпшити свою маркетингову стратегію компанії, що функціонують у сфері туризму, зараз можуть знайти дієві інструменти цифрового маркетингу. При цьому сучасні формати просування туристичних послуг витісняють традиційні інструменти.

Цифровий маркетинг - загальний термін, що використовується для позначення таргетивного та інтерактивного маркетингу товарів і послуг, що використовує цифрові інформаційні технології для залучення потенційних клієнтів та утримання їх як споживачів.

Цифровий маркетинг містить у собі Інтернет-маркетинг, а також будь-який прийом маркетингу, що пов'язаний із цифровою комунікацією. Загалом цифровий маркетинг можна визначити як використання мереж, створених за допомогою апаратного та програмного забезпечення в процесі маркетингу [1, с. 225].

Основні методи цифрового маркетингу, що застосовуються для розвитку туристичного бізнесу:

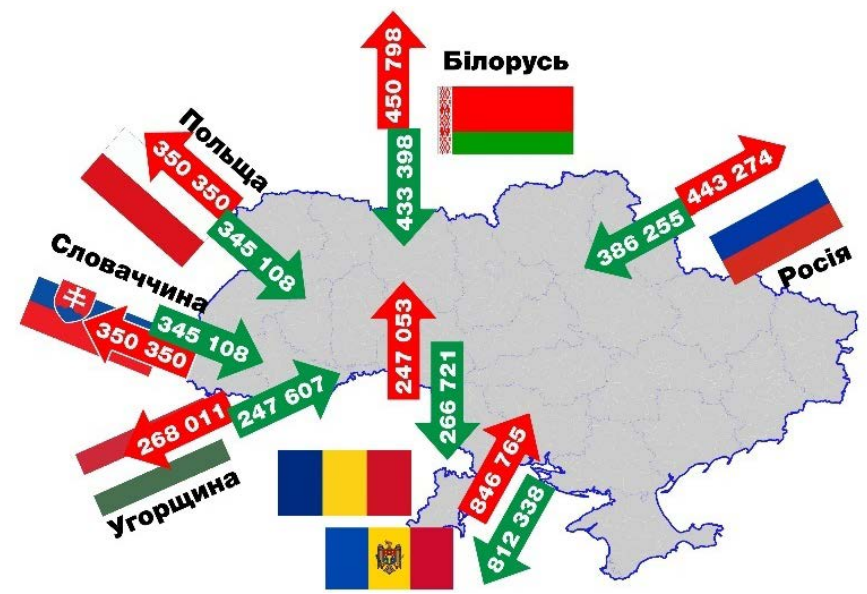

Рис. 1. Пропуск іноземних громадян через ділянки державного кордону Украӥни, 2020 р.

Джерело: авт. розр. за даними Державного агентства розвитку туризму Украӥни 


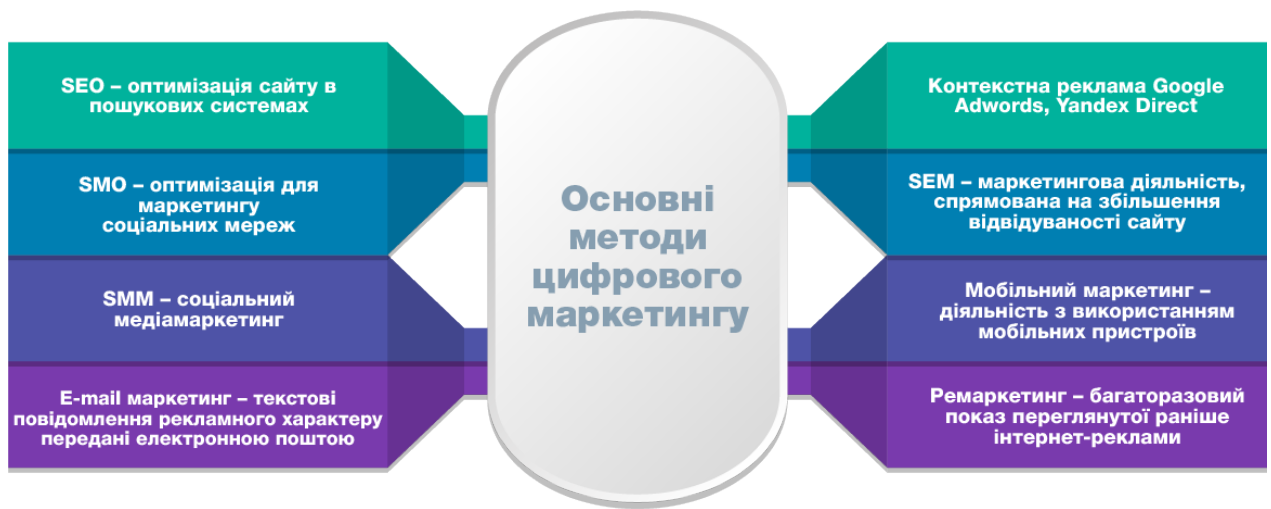

Рис. 2. Основні методи циифрового маркетингу у туристичному бізнесі Джерело: [5]

Зростає інтерес до автоматизації соціальних медіа та створення динамічного контенту, завдяки чому відбувається розроблення ефективної Інтернет-реклами, попит на яку можемо спостерігати з табл. 1.

Туризм на віртуальному ринку майже повністю залежить від якості, графічного дизайну, опису формату, засобів передачі та зберігання інформації. У цьому і полягає основна актуальність використання цифрових технологій у туризмі:

1. Доступ до великих цільових груп клієнтів задля передачі конкретної інформації.

2. Електронна презентація туристичної фірми.

3. Використання можливостей електронних міжнародних туристичних онлайнвиставок та каталогів.

4. Швидка обробка заявок клієнтів та бронювання необхідних послуг.

Обсяг рекламного ринку України, 2021 р.

\begin{tabular}{|c|c|c|c|c|c|}
\hline $\begin{array}{c}\text { Digital реклама } \\
\text { (за класифікацією IAB } \\
\text { Украӥна): } \\
\end{array}$ & $\begin{array}{l}\text { Підсумки } \\
2020 \text { р., } \\
\text { млн грн }\end{array}$ & $\begin{array}{l}\text { Підсумки } \\
2021 \text { р., } \\
\text { млн грн }\end{array}$ & $\begin{array}{c}\text { Відсоток } \\
\text { зміни } \\
2021 \text { до 2020 } \\
\end{array}$ & $\begin{array}{c}\text { Прогноз } \\
\text { на } 2022 \text { p., } \\
\text { млн грн } \\
\end{array}$ & $\begin{array}{c}\text { Відсоток } \\
\text { зміни } \\
2022 \text { до } 2021 \\
\end{array}$ \\
\hline $\begin{array}{c}\text { Банерна реклама, } \\
\text { оголошення у соціальних } \\
\text { мережах, richmedia }\end{array}$ & 3180 & 4780 & $50 \%$ & 5640 & $18 \%$ \\
\hline $\begin{array}{c}\text { Цифрове відео, вкл. } \\
\text { YouTube }\end{array}$ & 3800 & 6053 & $59 \%$ & 7869 & $30 \%$ \\
\hline $\begin{array}{c}\text { УСЬОГО ІНТЕРНЕТ- } \\
\text { МЕДІА }\end{array}$ & 6980 & 10833 & $55 \%$ & 13510 & $25 \%$ \\
\hline $\begin{array}{c}\text { Пошук (платна видача } \\
\text { в пошукових системах), } \\
\text { включаючи частину } \\
\text { GDN, щонайменше }\end{array}$ & 12300 & 17835 & $45 \%$ & 24969 & $40 \%$ \\
\hline Інфлюенсер-маркетинг & 336.8 & 505.2 & $50 \%$ & 707.28 & $40 \%$ \\
\hline Інший діджитал & 630 & 693 & $10 \%$ & 762.3 & $10 \%$ \\
\hline $\begin{array}{c}\text { УСБОГО IНТЕРНЕТ- } \\
\text { РИНОК }\end{array}$ & 20247 & 29867 & $48 \%$ & 39948 & $34 \%$ \\
\hline
\end{tabular}

Джерело: Всеукраӥнська рекламна коаліція (ВРК) 
5. Можливість клієнта самостійно формувати тури через онлайн-форми.

6. Гнучка взаємодія з партнерами на ринку.

7. Поширення повної та детальної інформації про свою діяльність.

8. Скорочення витрат на виробництво та поширення друкованої продукції.

9. Можливість організації віртуального офісу.

10. Маркетингові дослідження даних з Інтернет-мережі.

11. Використання електронних баз для побудови туристичних маршрутів.

12. Можливість аналізу ефективності прийнятої рекламної стратегії [6, с. 140].

Відповідно до Interactive Design Foundation, «графічний дизайн - це мистецтво створення візуального контенту для передачі повідомлень. Застосовуючи методи візуальної ієрархії та макета сторінки, графічні дизайнери використовують типографіку та зображення для задоволення конкретних потреб користувачів та зосереджуються на логіці відображення елементів в інтерактивному дизайні для оптимізації взаємодії 3 користувачем».

Завдяки графічному дизайну також досягається лідерство у цифровій диференціації конкурентів. Цифрова диференціація - це одна зі стратегій, яку компанії використовують для просування своїх товарів та послуг таким чином, щоб вони відрізнялися одна від одної:

- За графічним дизайном можна легко ідентифікувати компанію. Створення та демонстрація унікального стилю туристичної компанії - це спосіб забезпечити виняткову видимість; унікальний логотип, візитки, вебсайти та канали в соціальних мережах - усе це разюче контрастує з конкурентами.

- Якісний графічний дизайн підвищує цінність компанії, також це зміцнюєте авторитет та професійний імідж. Візуалізація не лише привертає увагу споживача, а й може стати ключем до завоювання довіри туристів, що дасть змогу легко розшири цільову аудиторію.

Наведемо ключові статистичні дані про графічний дизайн у цифровому маркетингу за 2021 р. (за даними affde.com: «Чому графічний дизайн важливий у цифровому маркетингу?»):

- Кількість уподобань та публікацій у соціальних мережах Infographics утричі більша, ніж у будь-якого іншого типу інформації.

- Глобальні витрати на мобільну рекламу в 2021 р. перевищили 350 млрд доларів.

- Відео та зображення публікуються на $1200 \%$ частіше, ніж текстова інформація або URL-посилання.

- Унікальний контент у поєднанні з рекламною графікою збільшує відвідуваність вебсайту до $2000 \%$.

Оскільки використання цифрового маркетингу в туристичному бізнесі зумовлює метод мобільного маркетингу, можемо на прикладі створення профілю у соціальній мережі Instagram навести зразки обов'язкових компонентів графічного дизайну для ефективної роботи сторінки та залучення клієнтів.

1. Цифровий логотип туристичного агентства:

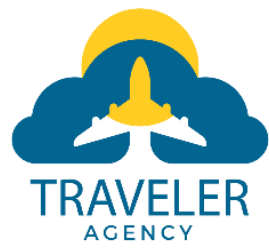

2. Іконки для постійних історій:

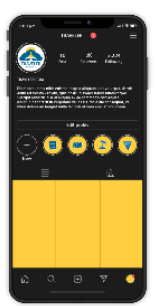

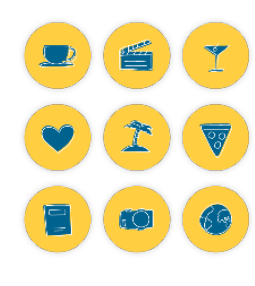


3. Дизайн оформлення історій профілю:

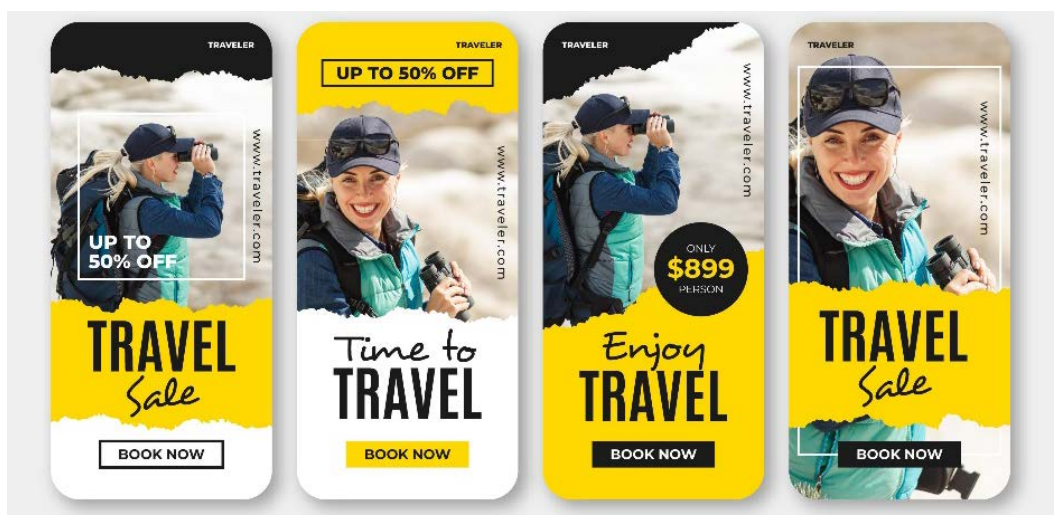

4. Шаблони для публікацій розважально-пізнавального контенту:

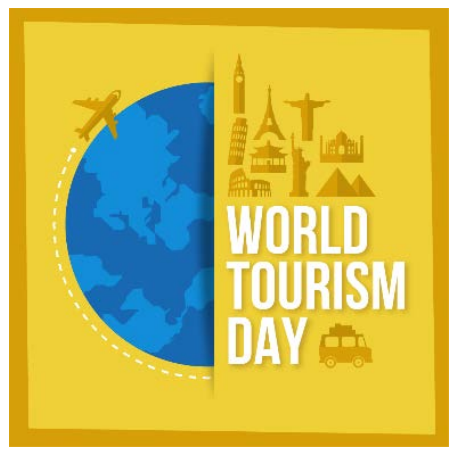

5. Рекламні макети для публікацій «Гарячих турів»:

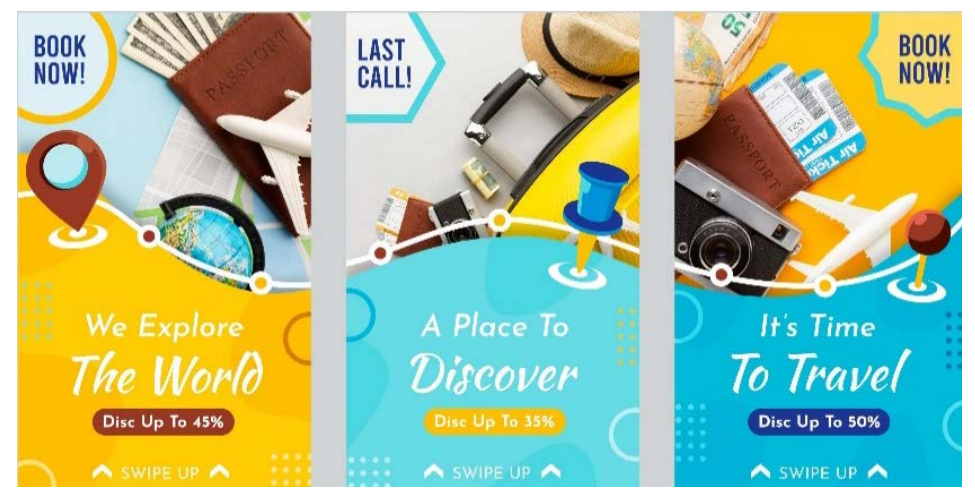

Із наведених макетів графічного контенту можемо зробити висновок, що туристична графіка інтуїтивно зрозуміла та в поєднанні з реальними фотографіями людей і мальовничих місць посилює рекламні художні ефекти, тим самим викликає емоційний резонанс клієнтів. Своєю чергою, це підсилює та $є$ завершальним етапом стратегії цифрового маркетингу. 
Висновки. Отже, за останні роки під впливом цифровізації туристичний бізнес в Україні та світі зазнав реформації та інтеграції із цифровим маркетингом. Його нова якісна форма спонукала появу революційних віртуальних методів просування бізнесу, що перейшов у віртуальну площину. Своєю чергою, це збільшило роль графічного дизайну, адже дизайн реклами визначає індивідуальність та впізнаваність бренду. Це візуальна ідентичність туристичного агентства, що формує нову цільову аудиторію та тим самим збільшує попит на туристичні послуги окремого представництва туристичного бізнесу.

\section{Список використаних джерел:}

1. Hofacker C.F. DigitalMarketing: communicating, sellingandconnecting. Massachusetts. Edward Elgar Publishing, Inc. 2018. 224 p.

2. Голда Н.М. Реклама у туристичному бізнесі. Теоретичні та прикладні аспекти розвитку економіки : матеріали III міжнар.наук.-практ. конф., м. Тернопіль, 25 квітня 2013 р. Тернопіль, 2013. C. $118-120$.

3. Ковальчук С.В., Лазебник М.Р. Ринок маркетингових комунікацій України: огляд та тенденції ринку. Маркетинг в Україні. 2016. № 3. С. 18-33.

4. Криховецький І.З. Методичні аспекти маркетингових досліджень у туризмі. Агросвіт. 2011. № 4. С. 54-60.

5. Цифровий маркетинг - модель маркетингу XXI сторіччя : монографія / М.А. Окландер, Т.О. Окландер, О.І. Яшкіна та ін. ; за ред. М.А. Окландера. Одеса : Астропринт, 2017. 292 с.

6. Папирян Г. А. Международные экономические отношения: маркетинг в туризме : учебно-методическое пособие. Санкт-Петербург : СПбГУ, 2017. 512 с.

7. Савицька Н.Л. Маркетинг у соціальних мережах: стратегії та інструменти на ринку В2С. Маркетинг і циифрові технологіï. 2017. № 1. С. 20-33.

\section{References:}

1. Hofacker C.F. Digital Marketing: communicating, selling and connecting. Massachusetts. Edward Elgar Publishing, Inc., 2018. 224 p.

2. Holda N.M. (2013) Reklama u turystychnomu biznesi [Advertising in the tourism business]. Proceedings of the Teoretychni ta prykladni aspekty rozvytku ekonomiky: materialy III mizhnar. nauk.prakt. konf. (Ukrainian, Ternopil, April 25, 2013), Ternopil, pp. 118-120.

3. Kovalchuk S. V., Lazebnyk M. R. (2016) Rynok marketynhovykh komunikatsii Ukrainy: ohliad ta tendentsii rynku [Marketing communications market of Ukraine: review and market trends]. Marketing in Ukraine, vol. 4, pp. 18-33.

4. Krykhovetskyi I. Z. (2011) Metodychni aspekty marketynhovykh doslidzhen u turyzmi [Methodical aspects of marketing research in tourism]. Agrosvit, vol. 4, pp. 54-60.

5. Oklander M.A., Oklander T.O., Yashkina O.I., etc (2017) Tsyfrovyi marketynh - model marketynhu XXI storichchia [Digital marketing is a 21 st century marketing model]. Odessa: Astroprint. (in Ukrainian).

6. Papyrian H. A. (2017) Mizhnarodni ekonomichni vidnosyny: marketynh u turyzmi [International economic relations: marketing in tourism]. St. Petersburg: SPbSU. (in Russian).

7. Savytska N.L. (2017) Marketynh u sotsialnykh merezhakh: stratehii ta instrumenty na rynku B2C [International Marketing: Strategies and Tools in the B2C Market]. Marketing and digital technologies, vol. 1, pp. 20-33. 